\title{
Analysis of Factors Affecting Financial Management Behavior
}

\author{
Yandi Suprapto, Santi Yopie \\ ${ }^{1}$ Management, Universitas Internasional Batam, Kota Batam \\ email: yandi.suprapto@uib.ac.id \\ ${ }^{2}$ Accounting, Universitas Internasioanal Batam, Kota Batam \\ email: santiyopie@uib.ac.id
}

\begin{abstract}
The purpose of this study is to determine the effect of risk profile, asset familiarity, investment objectives, investment awareness, and portfolio management on investment behavior. The method of collecting data using a questionnaire aimed at the people of Batam. A total of 100 questionnaires were collected and then processed using SPSS. The study continued with testing the validity and reliability. For testing the hypothesis the author uses multiple linear regression analysis. From this study it can be concluded that risk profile, asset familiarity, investment objectives, investment awareness, portfolio management have a significant positive effect on investment behavior. Overall the independent variable can explain the dependent variable by $51.8 \%$ while the rest is influenced by other variables outside the study.
\end{abstract}

Keywords: Portofolio Management, Investment Behaviour, Investment Awareness, Risk Profile, Investment Objective, Asset Familiarity.

\section{INTRODUCTION}

As the times evolve, people's understanding of the economy must also develop. However, knowledge and understanding of the economy is still very limited. The Financial Services Authority (OJK) notes that investment in the capital market sector is increasingly in demand by the people of Riau Islands Province. Where this is seen the increasingly high growth of investors in the province bordering the four neighboring countries. The capital market grew $58.86 \%$ and the Riau Islands people who are interested in transactions in the capital market, especially in stocks are very high. Of all capital market investors in the Riau Islands, as much as $74.28 \%$ of them are in Batam City, and only $25.72 \%$ are in other city districts in the Riau Islands (Ahmad Nabhani, 2018). Therefore, researchers want to examine the things that can affect investment behavior.
Understanding investment is an activity that aims to produce something that is desired or beneficial in the days to come. Before people start a business, it's good to find information on what products are good for investment. Investment products can be deposits, bonds, stocks, property and other investment products. Each investment product has a different investment risk and return.

When investors want to invest it should be adjusted to the funds they have. If you have a small fund, you should buy a deposit. If you have a lot of funds, you should invest in property. If investors want to meet future needs, then you should be able to make long-term investments because the benefits are consistent and the risks are lower. Meanwhile, when investors need funds quickly it is better to make short-term investments because the profits can be faster but the risk is greater. 
In investing, the factors that influence a person's type of investment are behavior. Behavior means that the activities that affect the investment process. Behavior can affect how a person uses information in making decisions. If the behavior in making investment decisions is wrong, it will adversely affect our finances.

The elements expected to be profitable in investing are grouped into two, namely objective and subjective. The objective factors are technological sophistication, price in production, and demand for products in the future, while subjective factors are experiences that have been felt by investors in the form of good or bad experiences.

Unclear investment creates rules called rules of thumb, which means rules that rely on experience and intuition. These rules are often used as guidelines, because many who have equated the things that will happen in the future will not be much different from the things that have happened before. As a result of this, investors will not always use these rules in investing, then subjective and objective things will not always be used by investors.

Every investor often has goals that are not well designed. When goals are not clearly explained, investors can make decisions that provide suboptimal returns. It is therefore best to clarify the investment objectives to get a clear understanding of what the portfolio will achieve. The investment objective of an investor refers to what an investor wants to achieve with his investment. Thus, an investor can invest for future financial security or save for children's education. Investors might also want to maximize current income. Besides investment risk is also a consideration for investors to invest because the investment objectives of investors are closely related to their risk tolerance. When an investor determines his investment objectives, it helps to determine the type of investment that will be chosen to achieve the goal. Based on portfolio theory, investors diversify or form a portfolio because they want to reduce risk. But there are also risks that are systematic in nature where this risk is greatly influenced by economic conditions, which when the economy improves will have a positive impact on the company, and vice versa if the economy deteriorates it will have a negative impact on the company. Economic conditions greatly affect certain types of industries and this is a systematic risk, so the intensity of the economic impact will be felt on companies that are sensitive to the state of the economy. The results of the study by Suriya et al., (2013) show that an investor pays more attention to the composition of the portfolio because it can affect long-term income, the results or profits obtained from the previous portfolio, advice or news published in print related to investment, and the most important thing is to consider the macroeconomic situation and the variables used in estimating the flow of funds in the future. An investment can be said to be profitable if the investment can make investors richer or investor prosperity levels become better after making an investment.

Another factor that is felt to affect one's investment behavior is asset familiarity. The level of familiarity or how far someone knows and recognizes an investment According to the findings of Shen et al., (2014) individuals tend to develop a strong interest in a particular investment just because they know and recognize the type of investment. This makes someone feel as though they have more knowledge or experience about such 
investment products so that they get a sense of comfort and security when choosing to invest in these investments.

Based on the discussion above, it can be said that the factors that influence investment behavior are the level of risk (risk profile), asset familiarity, investment targets (investment objectives), investment caution (investment awareness), and investment performance (portfolio management). So the authors intend to conduct research under the title " Analysis of Factors Affecting Financial Management Behavior".

\section{RESEARCH FRAMEWORK AND HYPOTHESIS DEVELOPMENT}

This study aims to find out the things that will affect the investment behavior of the people of Batam City in investing and examine what is the significant influence between the variables contained therein. The approach used in this study is quantitative research (quantitative research). Quantitative research is a study using primary data with a questionnaire to examine the cause and effect of investment behavior on risk profile, asset familiarity, investment objectives, investment awareness, portfolio management in the community in the city of Batam.

The total sample in this study was determined based on the method of Hair et al., (2011) where the number of indicators in the questionnaire was multiplied by five, then the number of respondents in this study was 90 respondents, adjusted to 100 respondents to anticipate the questionnaire that was not returned. The criteria for the research model taken are minimum age 18 years and beyond, communities in the city of Batam, the community must have a plan to invest.
The data used are data obtained through the distribution of 100 questionnaires among the people of Batam City. The questionnaire was only filled out by people of Batam City who planned to invest. Where the first question on the questionnaire asks about whether the respondent plans to invest.

Dickason and Ferreira (2018) conducted a study on establishing a relationship between risk tolerance, investor personality, and financial attitudes in South Africa. The purpose of his research is to obtain the influence of psychological biases on investment decisions. Psychological biases in this discussion relate to the level of risk tolerance and personal investors. Data collection by using a questionnaire distributed. The research sample is a client of an investment company and a total of 1171 investors. The independent variables used in this study are risk profile, investor personality and investment behavior as the dependent variable. Dervishaj (2018) conducts research on understanding or studying and explaining investor decisions and investor behavior due to the influence of psychological biases. In this study, investors in Albania were used as the research sample. The conclusion of the study is that the mindset of investors will influence investment decisions, and these effects are called psychological biases. The collection method in the study was carried out by distributing questionnaires. The independent variables used in this study are availability, anchoring, overconfidence, optimism, loss aversion, representativeness, mental accounting, endownment effects, herding, asset familiarity and investment behavior as dependent variables. Lippi et al., (2018) conducted a study with the aim to determine the behavior of investors in choosing the type of investment. Data collection was carried out using a 
questionnaire. The number of samples in the study were 1000 people. The sample in this study is among financial advisors and experts from investment companies. The independent variables contained in the study are risk profile and investment behavior as the dependent variable.

Seetharaman et al., (2017) conducted a study of factors influencing investment choices by investors in Singapore. The purpose of the research is to gain insight and information from factors that influence investors' investment plans in making portfolio decisions and the performance of investments. The data collection is done by distributing questionnaires. The object of research is investors in Singapore with a total sample of 250 where only 206 samples can be used for data analysis. The independent variables contained in the study are investment objectives, risk profiles, asset familiarity, and investment behavior as the dependent variable. Sarkar and Sahu (2017) conducted a study of factors influencing investor habits in the capital market. The purpose of this research is to analyze the factors that influence investor investment in the capital market. Data collection through the distribution of questionnaires to 500 samples. The sample in this study are investors located in the City of Bengal. The independent variables contained in the study are demographic factors, risk attitude, and investment behavior as the dependent variable. Kumar and Mankani (2017) conducted a study of female workers with investment vigilance in the City of Mumbai. The aim of the research is to study the difference in investment taken and the level of caution of educated women investors in the city of Mumbai. The number of samples is 500 samples. The sample in this study was among educated women investors in the city of Mumbai. The method used in this study uses 2 methods, the first through the distribution of questionnaires to the sample and the second through journals or articles contained in the local public. The independent variables contained in the study are investment awareness and investment behavior as the dependent variable.

De Vries et al., (2017) conducted a study with the aim of analyzing the effect of famility biases in the selection of investment products. The method of collecting data through questionnaires with 500 respondents. The independent variables contained in the study are asset familiarity and investment behavior as the dependent variable.

Rosemary et al., (2017) conducted a study with the aim of analyzing the objectives of the investment and the strategies used in achieving the objectives of investors in Nigeria. Methods of data collection through the distribution of questionnaires to the sample with a total sample of 130 samples. The samples in this study are investors in the cities of Lagos, Abuja, and Jos. The independent variables contained in the study are investment objectives, portfolio holdings, patronage of primary and secondary markets, information sources, and investment behavior as the dependent variable.

Charles and Kasilingam (2016) conducted research with the aim of analyzing the influence of investor income on investment decisions. Data collection through questionnaires. The number of questionnaires distributed as many as 780 and returned as many as 742 . The sample in the study were investors located in 32 districts of Tamilnadu. The independent variables contained in the study are investment awareness, portfolio management, and investment behavior as independent variables. Kauhisk (2016) conducted research on the determination of investor habits in mutual funds. The study was conducted in India using local 
investors as samples and data collection through questionnaires. The independent variables contained in the study are attitude, socio economic conditions, awareness level, risk, and investment behavior as the dependent variable. Riff and Yagil (2016) conducted a study on the effect of asset familiarity, asset fluency, risk profile on investment behavior where local residents were used as research samples and the method of data collection was carried out using a questionnaire. The independent variables contained in the study are asset familiarity, asset fluency, risk profile, and investment behavior as the dependent variable.

Hunt (2016) conducted research with the aim to determine the effect of selfcontrol on investment planning and the effect of investor financial planning and risk tolerance on investment planning. The independent variables contained in the study are self-control, optimism, financial literacy, risk profile, and investment behavior as the dependent variable. Kaur and Kaushik (2016) do with the aim to explain that investment behavior can be influenced by the prudence and economic conditions of investors. The study was conducted in the City of Delhi and the method of data collection through a questionnaire distributed to 500 respondents. Of the 500 respondents, 450 respondents can be used for further research. The independent variables contained in the study are investment awareness, investor attitude, socioeconomic conditions and investment behavior as the dependent variable.

Pak and Mahmood (2015) conducted research on the personal impact of risk tolerance and investment decisions. The purpose of this study is that investor behavior is related to the level of risk tolerance, which will affect the investment investment viability. The research method through qualitative methods is by measuring the level of risk tolerance. The independent variables contained in the study are personal characteristics, risk profile, and investment behavior as the dependent variable. Sharma (2015) conducted a study with the aim of finding the main objectives of the mutual fund scheme of investors and the types of mutual funds that were most popular. Data collection was carried out by distributing questionnaires, book journals and newspapers. The number of questionnaires distributed was 100 sheets and the object of the study was mutual fund investors in the city of Faridabab. The results of this study conclude that the mutual fund scheme can produce benefits, low risk and low investment tax. The independent variables contained in the study are investment objectives and investment behavior as the dependent variable. Hoffmann et al., (2015) conducted research on how investors' habits in risk perception and their actions in investing. The purpose of investment is to find out how financial behavior can influence investor perceptions. The method of collecting data through online surveys with a sample of 2000 respondents where the respondents are brokers in the Netherlands. From 2000 respondents, only 1510 respondents could proceed to the next analysis. The independent variables contained in the study are risk tolerance, risk perception, return expectation and investment behavior as the dependent variable. Islamoglu et al., (2015) conducted a study with the aim to find out what factors influence investor behavior. The method of collecting data through the distribution of questionnaires with research objects is a bank employee. The number of questionnaires distributed were 215 and which could be used for analysis were 211. The independent variables contained in the study were income level, past 
investment experience, opinion, asset familiarity, and investment behavior as the dependent variable.

Imthiyas et al., (2015) examined how media such as newspapers, magazines, journals, electronic media, professional investor associations can raise investment awareness in Chennai, India in influencing investment behavior. In this study, the number of samples obtained from the distribution of questionnaires was 573 . The sampling method used was convenience non probalistic sampling where the samples were categorized based on income level and several other factors. The independent variable in this study is investment awareness and the dependent variable is investment behavior.

From the explanation above, the hypothesis for this research is as follows: $\mathrm{H}_{1}$ : Risk profile has a significantly positive effect on investment behavior.

$\mathrm{H}_{2}$ : Asset familiarity has a significantly positive effect on investment behavior.

$\mathrm{H}_{3}$ : Investment objectives have a significantly positive effect on investment behavior.

$\mathrm{H}_{4}$ : Investment awareness has a significantly positive effect on investment behavior.

$\mathrm{H}_{5}$ : Portfolio management has a significantly positive effect on investment behavior.

\section{RESULTS AND DISCUSSION}

The results obtained state that all variables are considered valid because the factor loading value is> 0.6 , then the overall variables are declared valid (Ghozali, 2013). In this study, the Cronbach's Alpha value of all the above variables is from 0.6 so each variable is a reliable variable also.

By using the P-plot and Kolmogorov Smirnov images, it can be seen that the points spread on the diagonal line, it can be concluded that the data is normally distributed (Ghozali, 2013). The results of the multicollinearity test the test criteria are if the VIF value is above 0.1 and the tolerance value is below 10 , then it can be concluded that there is no multicollinearity (Ghozali, 2013). Glejser test results to see models that contain heteroscedasticity or the absence of heteroscedasticity (Ghozali, 2013). Heteroscedasticity is considered if the $\mathrm{t}$ test output $>0.05$. From the testing that has been done, it is concluded that all variables are free from heteroscedasticity. The $\mathrm{F}$ test is tested by observing the value of its significance and if the value is lower than 0.05 then the regression model can be used to estimate the dependent variable (Ghozali, 2013).

Hypothesis 1: Analysis of the Effect of Risk Profile on Investment Behavior. The results of these tests obtained significant values at 0.027 , it can be concluded that there is a positive significant effect between the risk profile variables on the investment behavior variable. The results of this study found that if an investor carries out risk profiling well, such as if the investor is a risk-averse investor, then the choice of invested shares must be lowrisk according to his risk profile. If an investor does not follow his risk profile in choosing stocks, the results of his investment behavior will not be optimal (Seetharaman et al., 2017).

Hypothesis 2: Analysis of the Effect of Asset Familiarity on Investment Behavior. The test results get significant values at 0.001 then we can conclude that there is a significant positive effect between the variable asset familiarity to the variable investment behavior. The results of this study found that if an investor is more familiar with and has information about the assets invested, the resulting investment behavior will be better (Seetharaman et al., 2017). 
Hypothesis 3: Analysis of the Effect of Investment Objectives on Investment Behavior. The test results get significant values at 0.047 , we can conclude that there is a significantly positive effect between investment objective variables on investment behavior variables.. The results of this study found that the higher the investment target of an investor, the more it will affect investment behavior because someone who has an investment goal, the investor will try to achieve these goals by all means so that investors will try to avoid mistakes in investing. The results of the study are consistent and in accordance with previous studies (Seetharaman et al., 2017).

Hypothesis 4: Analysis of the Effect of Investment Awareness on Investment Behavior. The test results get significant values at the number 0.043 , we can conclude that there is a significantly positive effect between investment awareness variables on investment behavior variables. The results of this study found that if an investor has a level of awareness of information that affects his investment in the form of current information and prior experience. Then, investors can apply investment behavior that is profitable for him. (Charles and Khasilingam, 2016).

Hypothesis 5: Analysis of the Effect of Portfolio Management on Investment Behavior. The test results get significant values at the number 0.038 , we can conclude that there is a significantly positive effect between the variable portfolio management on the variable investment behavior. The results of this study found that if an investor has a good investment management portfolio, then investment behavior will also be better, because investors who have good portfolio management have the ability to diversify to reduce the risks they take.
The results of the study are consistent and in accordance with previous studies (Charles and Khasilingam, 2016).

From the test results the coefficient of determination shows the magnitude of the influence of variables on the model under study. Number of 0.518 which means that the ability of the independent variable in explaining the variable of investment behavior is $51.8 \%$ while the remaining $48.2 \%$ is explained by other variables not present in this study.

\section{CONCLUSIONS}

According to the above research and the results and discussion of each chapter, several conclusions can be made as follows:

The results of these tests obtained significant values at 0.027 , it can be concluded that there is a positive significant effect between the risk profile variables on the investment behavior variable. The results of this study found that the better the risk profile of an investor, the better the results of his investment behavior.

2. The test results get significant values at 0.001 , we can conclude that there is a significantly positive effect between the variable asset familiarity to the investment behavior variable. The results of this study found that if an investor is more familiar with and has information about the assets invested, the resulting investment behavior will be better.

3. The test results get significant values at the number 0.047 , we can conclude that there is a significant positive effect between the investment objective variable on the investment behavior variable. The results of this study found that the higher the investment 
target of an investor, the more it will affect investment behavior because someone who has an investment goal, the investor will try to achieve these goals by all means so that investors will try to avoid mistakes in investing.

4. The test results get significant values at 0.043 then we can conclude that there is a significantly positive effect between investment awareness variables on investment behavior variables. The results of this study found that the greater the vigilance of a person the investor influences investment behavior.

5. The test results get significant values at 0.038 , we can conclude that there is a significant positive effect between portfolio management variables on investment behavior variables. The results of this study found that if an investor has a good investment management portfolio, then investment behavior will also be better, because investors who have good portfolio management have the ability to diversify to reduce the risks they take.

\section{ACKNOWLEDGMENT}

In completing this research, the author is very grateful to Universitas Internasional Batam, which has provided much support.

\section{DAFTAR PUSTAKA}

Aren \& Zengin (2016). Influence of Financial Literacy and Risk Perception on Choice of Investment. Procedia - Social and Behavioral Sciences,235(October),656-663.

Bhushan (2014). Relationship between Financial Literacy and Investment Behavior of Salaried Individuals. Journal of Business Management \& Social Sciences Research, 3(5), 2319-5614.

Bishnoi (2014). Relation Between
Investment Objectives and Demographic Variables. Journal of General Management Research, 1(1), 91-107.

Charles \& Kasilingam (2016). Retail Investors Investment Behaviour and Their Income- an Analytical Study of Indian Rquity Market. Journal of Management Research, 7(2), 179188.

Chen, Cheng., \& Lee (2011). The Behavior of Taiwanese Investors in Asset Allocation. Asia-Pacific Journal of Business Administration, 3(1), 62-74.

De Vries, Erasmus, \& Gerber (2017). The Familiar Versus the Unfamiliar: Familiarity Bias amongst Individual Investors. Journal of Management Sciences, 17(1), 1-10.

Dervishaj (2018). Psychological Biases, Main Factors of Financial Behaviour - A Literature Review. European Journal of Natural Sciences and Medicine, 1(2), 25.

Dickason \& Ferreira (2018). Establishing a Link between Risk Tolerance, Investor Personality and Behavioural Finance in South Africa. Journal of Economics \&Finance, 6(1), 1-13.

Ghozali, (2013). Aplikasi Analisis Multivariate dengan Program IBM SPSS 21 Update PLS Regresi. Badan Penerbit Universitas Diponegoro. Semarang.

Gnani, D., Ganesh, \& Santhi. (2012). A Study on the Individual Investor Behavior with Special Referance to Geojit BNP Paribas Financial Service Ltd , Coimbatore. International Journal of Management and Technology (IJRMT), 2(2), 243-252.

Hair, Jr., Joseph F., et. al. (2011). Multivariate Data Analysis. Fifth Edition. New Jersey: PrenticeHall, Inc. 
Hoffmann,, Post, T., \& Pennings, J. M. E. (2015). How Investor Perceptions Drive Actual Trading and RiskTaking Behavior. Journal of Behavioral Finance, 16 (1), 94-103.

Hon, T. (2012). The Behaviour of Small Investors in the Hong Kong Derivatives Markets: A Factor Analysis. Journal of Risk and Financial Management, 5, 59-77

Hunt, K. (2016). Investment Risk Profiling: Lessons From Psychology. Financial Planning Research Journal, 1(1), 49-63.

Imthiyas, Shyamasundar, \& R. (2015). A Study on reach of Investment Awareness Programmes Organized by E-Governance Services over Social Media. International Journal of Applied Environmental Sciences, 10(1), 65-69.

Islamoğlu, M., Apan, M., \& Ayvali, A. (2015). Determination of Factors Affecting Individual Investor Behaviours: A Study on Bankers. International Journal of Economics and Financial Issues, 5(2), 531-543. Jagongo, A., \& Mutswenje, V. (2014). A Survey of the Factors Influencing Investment Decisions: The Case of Individual Investors at NSE. Journal of Environmental Health, 4(4), 25 28 .

Kaur, I., \& Kaushik, K. P. (2016). Determinants of Investment Behaviour of Investors Towards Mutual Funds. Journal of Indian Business Research, 8(1), 19-42.
Kumar \& Mankani. (2017). A Study of Level of Awareness Regarding Investment Avenues among Educated Working Women with Special Reference to Mumbai City. International Journal of Research in Economics and Social Sciences7(9), 271-277.

Lippi, A., Barbieri, L., Piva, M., \& De Bondt, W. (2018). Time-varying Risk Behavior and Prior Investment Outcomes: Evidence from Italy. Judgment and Decision Making, 13(5), 471-483.

Riff, S., \& Yagil, Y. (2016). Behavioral Factors Affecting the Home Bias Phenomenon: Experimental Tests. Journal of Behavioral Finance, 17(3), 267-279.

Rosemary, Msheliza, S. K., \& Bulus, H. (2017). Investment Objectives and Strategies of Individual Investors in the Nigerian Capital Market. International Peer-reviewed Journal. Vol.40, 2017. 87.

Sarkar, A. K., \& Sahu, T. N. (2017). Factors influencing behaviour of individual investor in stock market: a case study in West Bengal. International Journal of Commerce and Management Research.

Seetharaman, A., Niranjan, I., Patwa, N., \& Kejriwal, A. (2017). A Study of the Factors Affecting the Choice of Investment Portfolio by Individual Investors in Singapore. Accounting and Finance Research, 6(3), 153. 